\title{
Implementasi Enterprise Architecture Zachman Framework pada Sistem Informasi Akademik Universitas Dian Nuswantoro Semarang
}

\author{
Implementation of Enterprise Architecture Zachman Framework in the Academic \\ Information System of Dian Nuswantoro University Semarang \\ Yupie Kusumawati ${ }^{1}$, Melati A. Sitorus ${ }^{2}$, Ramadhan Rakhmat Sani ${ }^{3}$ \\ 1,2,3 Fakultas Ilmu Komputer, Universitas Dian Nuswantor Semarang \\ e-mail: 1'yupie@dsn.dinus.ac.id , ${ }^{2} 112201505297 @$ mhs.dinus.ac.id, \\ ${ }^{3}$ ramadhan_rs@dsn.dinus.ac.id
}

\begin{abstract}
Abstrak
penting dalam mendukung terlaksananya proses perkuliahan di UDINUS. Namun dalam melaksanakan tugas dan tanggung jawab PDI memiliki permasalahan, dimana terjadi error pada Sistem Informasi Akademik Universitas Dian Nuswantoro (SIADIN) saat dioperasikan oleh user dan kurangnya integrasi antar sistem. Dalam menangani error tersebut PDI mengecek kode program dan melakukan perbaikan, namun untuk porgrammer yang belum mengetahui proses pembangunan dan pengembangan SIADIN memiliki kesulitan dalam melakukan perbaikan error (penambahan fungsi) yang dibutuhkan. Kesulitan tersebut disebabkan oleh beberapa hal yaitu kurangnya dokumentasi yang dimiliki terkait dengan pembangunan sistem, stakeholder tidak dilibatkan sepenuhnya, kemampuan dalam melakukan analisis terhadap potensi kemungkinan adanya kesalahan sangat minim dan tidak mempunyai framework sebagai acuan pengembangan SIADIN. Maka dari itu penelitian ini dilakukan untuk menciptakan blueprint IT sistem informasi akademik pada core process dan Prototype sistem informasi akademik pada admin yang dikembangkan berdasarkan blueprint IT dengan menggunakan Zachman Framework sebagai kerangka kerja enterprise architecture untuk melakukan dokumentasi terhadap pengembangan sistem dengan memetakan kedalam 36 sel. Dari penelitian ini diperoleh blueprint IT dan prototype berbasis Objected Oriented Programming yang dapat digunakan sebagai acuan untuk membangun, mengembangkan dan mendokumentasikan sistem.
\end{abstract}

Kata kunci: Enterprise Architecture, Zachman Framework, Blueprint IT

\begin{abstract}
Pusat Data dan Informasi (PDI) is one of the technical implementation units that has an important role in supporting the implementation of the lecture process at UDINUS. But in carrying out the duties and responsibilities of the PDI has problems, where there was an error in the Academic Information System of Dian Nuswantoro University (SIADIN) when operated by the user and lack of integration between systems. In dealing with these errors PDI checks the program code and makes repairs, but for programmers who do not know about the development and development process of SIADIN have difficulties in making repairs to errors (additional functions) needed. The difficulty is caused by several things, namely the lack of documentation that is owned related to system development, stakeholders are not fully involved, the ability to analyze potential potential errors is very minimal and does not have a framework as a reference for SIADIN development. Therefore, this study was conducted to create an IT blueprint of academic information systems at the core process and Prototype of academic information systems in admin developed based on IT blueprints by using the Zachman Framework as an enterprise architecture framework to document system development by mapping into 36 cells. From this
\end{abstract}

Journal of Information System Vol. 4, No. 1, Mei 2019, hlm. 98-109

p-ISSN : 2528-0228

e-ISSN : 2528-0236 
research, IT blueprints and prototypes based on Objected Oriented Programming can be used as a reference to build, develop and document the system.

Keywords: Enterprise Architecture, Zachman Framework, Blueprint IT

\section{PENDAhULUAN}

Enterprise digunakan untuk mencapai keselarasan antara TI/SI dengan tujuan serta proses bisnis, dimana perguruan tinggi juga memerlukan adanya arsitektur dengan jelas seperti pada umumnya disebut enterprise architecture (EA). Berdasarkan data yang diperoleh informasi diketahui bahwa PDI memiliki tugas untuk mengelola, mengkoordinasi, memonitor, mengevaluasi dan mengembangkan sekitar 30 sampai 40 aplikasi dengan berbagai macam permintaan yang dibutuhkan masing-masing unit bagian yang berbeda-beda. Tidak jarang sistem informasi akademik yang dikelola PDI menghasilkan kesalahan atau error saat dioperasikan. Misalnya pada saat mahasiswa (user) login di SIADIN dan sistem akan merespon dengan proses login, dengan saat yang sama user tersebut menekan tombol ESC dan sistem secara langsung menutup halaman login serta menampilkan halaman admin. Dalam menangani error tersebut PDI mengecek kode program dan melakukan perbaikan, namun untuk porgrammer yang belum mengetahui proses pembangunan dan pengembangan SIADIN memiliki kesulitan dalam melakukan perbaikan error (penambahan fungsi) yang dibutuhkan. Kesulitan tersebut disebabkan oleh beberapa hal yaitu kurangnya dokumentasi yang dimiliki terkait dengan pembangunan sistem, stakeholder tidak dilibatkan sepenuhnya, kemampuan dalam melakukan analisis terhadap potensi kemungkinan adanya kesalahan sangat minim dan tidak mempunyai framework sebagai acuan pengembangan SIADIN.

Beberapa penelitian yang berhubungan dengan penelitian ini sering digunakan, misalnya penelitian [1] dengan objek penelitan pada UMKM Jawa Tengah untuk perancangan pengembangan Enterprise Architecture menggunakan metode Zachman Framework pada tahun 2017 yang sekaligus dilakukan pengimplemtasian sistem informsi berbentuk website. Penelitian [2] dilakukan pada tahun 2017 di Universitas Pembangunan Nasional Veteran Jakarta dengan tujuan untuk melakukan perencanaan strategis TI/SI. Perencanaan startegis TI/SI dilakukan dengan menggunakan pendekatan Enterprise Architecture Planning (EAP) dalam Zachman framework yang disesuaikan dengan arah dan perkembangan institusi. Hasil dari penelitian ini adalah model kerangka kerja rencana strategis TI/SI berupa rancangan arsitektur dan tata kelola TI yang dilengkapi dengan roadmap. Penelitian [3] dimana objek yang digunakan STT Dharma Iswara Madiun, sehingga dibuat dokumen rencana induk (Master Plan) menggunakan framework Zachman 4 kolom dan 3 baris. Master plan yang dimaksud merupakan perencanaan strategis dan perancangan Architecture Enterprise terkait Sistem Informasi Akademik. Penelitian[4] dilakukan pada Sekolah Tinggi Pariwisata (STP) Trisakti dengan tujuan untuk melakukan perencanaan strategis sistem dan teknologi informasi dibuat berdasarkan Ward \& Peppart framework dan Enterprise Architecture framework yang dipetakan kedalam Zachman framework dengan hasil blueprint IT. Penelitian yang terakhir [5] yaitu melakukan penelitian pada Politeknik Jambi dengan tujuan untuk membangun asitektur enterprise sebagai pedoman dalam membangun sistem informasi akademik yang terintegrasi sesuai dengan tujuan institusi dengan menggunakan metode Zachman framework.

Pada penelitian ini dilakukan perancangan, pengembangan dan implementasi enterprise architecture dengan menggunakan Zachman Framework sebagai panduan untuk memetakan kedalam 36 sel kerangka kerja zachman, dan menggunakan data serta informasi yang diperoleh dari Pusat Data dan Informasi (PSI) UDINUS. Pada penelitian sebelumnya hanya memetakan kedalam beberapa sel kerangka kerja. Penelitian ini fokus untuk memetakan kedalam setiap perspektif kebutuhan dalam 36 sel kerangka Zachman yang menghasilkan blueprint IT dan prototype berdasarkan pemetaan. 


\section{METODE PENELITIAN}

Adapun metode yang digunakan dalam penelitian ini yaitu metode penelitian dan metode analisis yang ditunjukkan dengan Gambar 1 dan Gambar 2 sebagai berikut ini:

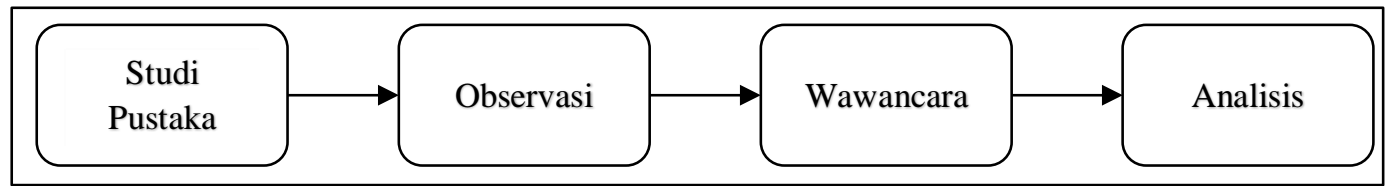

Gambar 1. Tahapan penelitian

\begin{tabular}{|c|c|c|c|c|c|c|}
\hline $\begin{array}{l}\text { Abstraksi/ } \\
\text { Persfektif }\end{array}$ & What Data (Thing) & $\begin{array}{l}\text { How Function } \\
\text { (Process) }\end{array}$ & $\begin{array}{l}\text { Where Network } \\
\text { (Location) }\end{array}$ & Who People (People) & When Time (Time) & $\begin{array}{c}\text { Why } \\
\text { Motivation } \\
\text { (Motivation) }\end{array}$ \\
\hline Planner & $\begin{array}{l}\text { Data yang berkaitan } \\
\text { dengan Sistem } \\
\text { Informasi Akademik } \\
\text { diantaranya yaitu } \\
\text { data mhasiswa, data } \\
\text { dosen, data KRS, } \\
\text { data mata kuliah, } \\
\text { data nilai, data } \\
\text { absensi, data ruang, } \\
\text { data kurikulum, data } \\
\text { tagihan, dan data } \\
\text { pembayaran. }\end{array}$ & $\begin{array}{l}\text { Proses bisnis utama } \\
\text { yang terjadi pada PDI } \\
\text { yaitu membangun, } \\
\text { mengelola, merawat } \\
\text { dan mengembangkan } \\
\text { Sistem Informasi } \\
\text { khususnya Sistem } \\
\text { Informasi Akademik }\end{array}$ & $\begin{array}{l}\text { Lokasi proses } \\
\text { bisnis PDI berada } \\
\text { (peta) }\end{array}$ & $\begin{array}{l}\text { Orang yang berperan } \\
\text { penting dalam proses } \\
\text { bisnis utama PDI } \\
\text { yaitu mengelola dan } \\
\text { mengembangkan } \\
\text { Sistem Informasi } \\
\text { Akademik }\end{array}$ & $\begin{array}{l}\text { Kejadian-kejadian } \\
\text { (events) yang terjadi } \\
\text { pada Sistem Informasi } \\
\text { Akademik }\end{array}$ & $\begin{array}{l}\text { Visi dan misi yang } \\
\text { dimiliki Pusat Data } \\
\text { dan Informasi (PDI) }\end{array}$ \\
\hline $\begin{array}{l}\text { Enterprise } \\
\text { Model }\end{array}$ & $\begin{array}{l}\text { - Use Case System } \\
\text { - Flowmap } \\
\text { - Entitas } \\
\text { relationship } \\
\text { Diagram (ERD) } \\
\text { - Entitas } \\
\text { Dictionary } \\
\text { - UML } \\
\text { - IDEF1X }\end{array}$ & $\begin{array}{l}\text { - Activity Diagram } \\
\text { - Work Flow } \\
\text { - Physical Data Flow } \\
\text { - Process Dictionary } \\
\text { - Skenario Use Case } \\
\text { - GRAI Nets } \\
\text { - UML Act. Diag } \\
\text { - Sys/Sub.sys.vs } \\
\text { Processes Matrix }\end{array}$ & $\begin{array}{l}\text { - Desain jaringan } \\
\text { yang telah } \\
\text { dimiliki PDI } \\
\text { - UML Packages } \\
\text { - Functional } \\
\text { Logistic System } \\
\text { - Denah Gedung }\end{array}$ & $\begin{array}{l}\text { - Organization } \\
\text { Chart } \\
\text { - GRAI Grid } \\
\text { - SDM yang } \\
\text { bertugas dalam } \\
\text { mebangun dan } \\
\text { mengelola sistem } \\
\text { - Use case } \\
\text { - SDM yang terlibat }\end{array}$ & $\begin{array}{l}\text { - Time schedule } \\
\text { pembangunan } \\
\text { Sistem Informasi } \\
\text { Akademik baru } \\
\text { (SIADIN versi 2) } \\
\text { dengan GANTT } \\
\text { CHART } \\
\text { - Project Master } \\
\text { Schedule } \\
\text { - IDEF3 OSTN } \\
\text { (object State } \\
\text { Transition } \\
\text { Network) }\end{array}$ & $\begin{array}{l}\text { - Tujuan / alasan } \\
\text { dalam } \\
\text { pengembangan } \\
\text { Sistem Informasi } \\
\text { Akademik } \\
\text { - Business tools }\end{array}$ \\
\hline $\begin{array}{l}\text { System } \\
\text { Model } \\
\text { Designer }\end{array}$ & $\begin{array}{l}\text { - Logical } \\
\text { ERD/ERM } \\
\text { IDEFLX } \\
\text { - Class diagram } \\
\text { - Aset/entitas } \\
\text { penting organisasi }\end{array}$ & $\begin{array}{l}\text { - Detailed Use Case } \\
\text { - Sequence Diagram } \\
\text { - Use case } \\
\text { - System Process } \\
\text { Dictionary } \\
\text { - Processes vs } \\
\text { Entities Matrix }\end{array}$ & $\begin{array}{l}\text { - UML } \\
\text { Component } \\
\text { - Desain Jaringan } \\
\text { usulan } \\
\text { - Representasi } \\
\text { Lokasi } \\
\text { - System diagram }\end{array}$ & $\begin{array}{l}\text { - Rancangan } \\
\text { Manual Interface } \\
\text { aplikasi } \\
\text { - Use case } \\
\text { - Rolex Matrix } \\
\text { - Rancangan Input/ } \\
\text { output } \\
\text { - GRAI Grid }\end{array}$ & $\begin{array}{l}\text { - Statechart diagram } \\
\text { - Detail jadwal } \\
\text { perancangan model } \\
\text { (GANTT Chart) } \\
\text { - Durasi aktivitas } \\
\text { pengembangan } \\
\text { Sistem Informasi } \\
\text { Akademik } \\
\text { - IDEF3 }\end{array}$ & $\begin{array}{l}\text { - FOL (First Order } \\
\text { Logistic) } \\
\text { - Aturan } \\
\text { Perancangan Model } \\
\text { - Decision Table }\end{array}$ \\
\hline $\begin{array}{l}\text { Technology } \\
\text { Model } \\
\text { Builder }\end{array}$ & $\begin{array}{l}\text { - } \text { IDEFIX (Inf } \\
\text { Model) } \\
\text { - Class Diagram } \\
\text { - Relasi antar tabel }\end{array}$ & $\begin{array}{l}\text { - Activity structure } \\
\text { Chart } \\
\text { - UML Class } \\
\text { - IDEFO } \\
\text { - Sequence Diagram } \\
\text { - Diagram alur proses } \\
\text { fisik }\end{array}$ & $\begin{array}{l}\text { - Lokasi dan } \\
\text { teknologi yang } \\
\text { digunakan PDI } \\
\text { - Skema jaringan } \\
\text { - Tata letak ruang } \\
\text { yang digunakan } \\
\text { - UML } \\
\text { Deployment }\end{array}$ & $\begin{array}{l}\text { - Deskripsi actor } \\
\text { dari diagram use } \\
\text { case } \\
\text { - Gambar interfaces } \\
\text { Sistem Informasi } \\
\text { Akademik (GUI) } \\
\text { - Use case } \\
\text { - Gambar imput } \\
\text { output aplikasi }\end{array}$ & $\begin{array}{l}\text { - UML Sequence dan } \\
\text { Collaboration Diag } \\
\text { - Detail jadwal } \\
\text { perancangan Sistem } \\
\text { Informasi } \\
\text { Akademik }\end{array}$ & $\begin{array}{l}\text { - FOL (First Order } \\
\text { Logistic) } \\
\text { - Aturan } \\
\text { Perancangan Model } \\
\text { - Decision Table }\end{array}$ \\
\hline $\begin{array}{l}\begin{array}{l}\text { Detailed } \\
\text { Description }\end{array} \\
\text { Sub- } \\
\text { Contractor }\end{array}$ & $\begin{array}{l}\text { - Querry Database } \\
\text { - DB Schema } \\
\text { - Algoritma } \\
\text { pembutan table- } \\
\text { tabel entitas }\end{array}$ & $\begin{array}{l}\text { - Program languages } \\
\text { - Scenario use case } \\
\text { - Activity diagram } \\
\text { - Algoritma proses } \\
\text { utama sistem }\end{array}$ & $\begin{array}{l}\text { - Konfigurasi } \\
\text { router jaringan } \\
\text { - TCP/IP } \\
\text { - Spesfiikasi } \\
\text { harchvare dan } \\
\text { software } \\
\text { - URL }\end{array}$ & $\begin{array}{l}\text { - Kategori } \\
\text { interfaces } \\
\text { - Konfigurasi hak } \\
\text { akses user pada } \\
\text { Sistem Informasi } \\
\text { Akademik }\end{array}$ & $\begin{array}{l}\text { Detail jadwal } \\
\text { proses coding yang } \\
\text { dibutuhkan dalam } \\
\text { membangun Sistem } \\
\text { Informasi } \\
\text { Akademik (GANTT } \\
\text { CHART) }\end{array}$ & $\begin{array}{l}\text { - Aturan-aturan } \\
\text { dalam proses } \\
\text { coding }\end{array}$ \\
\hline $\begin{array}{l}\text { Functioning } \\
\text { Enterprise }\end{array}$ & $\begin{array}{l}\text { - Contoh data yang } \\
\text { berkaitan dengan } \\
\text { sistem diisikan di } \\
\text { setiap table }\end{array}$ & $\begin{array}{l}\text { - Contoh hasil print } \\
\text { out proses utama } \\
\text { sistem } \\
\text { - Contoh data } \\
\text { transaksi yang } \\
\text { terjadi di dalam } \\
\text { Sistem Informasi } \\
\text { Akademik }\end{array}$ & $\begin{array}{l}\text { - Infrastruktur } \\
\text { jaringan } \\
\text { pendukung yang } \\
\text { dibutuhkan }\end{array}$ & $\begin{array}{l}\text { - User yang akan } \\
\text { menggunakan } \\
\text { sistem }\end{array}$ & $\begin{array}{l}\text { - Time Schedule } \\
\text { proses } \\
\text { perancangan, } \\
\text { desain dan } \\
\text { implementasi }\end{array}$ & $\begin{array}{l}\text { - Prosedur, panduan } \\
\text { penggunaan sistem } \\
\text { informasi (SOP) }\end{array}$ \\
\hline
\end{tabular}

Gambar 2. Tahapan analisis 
Pada gambar 2 tahapan analisis meliputi perspekif planner, perspektif owner, perspektif designer, perspektif builder, perspektif detail representation dan perspektif function enterprise dengan menggunakan 6 abstraksi yaitu what, how, where, who, when dan why.

\section{HASIL DAN PEMBAHASAN}

\subsection{Perspektif Planner (Scope)}

Pada bagian ini menjabarkan arsitektur kontekstual yang berisikan bisnis fungsional yang dipetakan berdasarkan 6 abstraksi seperti pada tabel 1 .

Tabel 1. Pemetaan perspektif Planner terhadap 6 Abstraksi

\begin{tabular}{|c|c|c|}
\hline No. & Abstraksi & Keterangan \\
\hline 1 & $\begin{array}{l}\text { Data } \\
\text { (What) }\end{array}$ & $\begin{array}{l}\text { Data dosen, data mahasiswa, data matakuliah, data absensi, data } \\
\text { krs (kartu rencana studi), data ruang kelas, data nilai, data } \\
\text { tagihan, data pembayaran. }\end{array}$ \\
\hline 2 & $\begin{array}{l}\text { Fungsi } \\
\text { (How) }\end{array}$ & $\begin{array}{l}\text { Proses pendaftaran mahasiswa baru, proses pembuatan jadwal } \\
\text { dosen, proses penilaian, proses penjadwalan perkuliahan } \\
\text { mahasiswa, proses pembagian kelas, proses absensi, proses } \\
\text { tagihan perkuliahan, proses pembayaran tagihan. }\end{array}$ \\
\hline 3 & $\begin{array}{l}\text { Jaringan } \\
\text { (Where) }\end{array}$ & Lokasi Pusat Data dan Informasi Universitas Dian Nuswantoro \\
\hline 4 & $\begin{array}{l}\text { Orang } \\
\text { (Who) }\end{array}$ & $\begin{array}{l}\text { Mahasiswa, dosen, program studi, biro akademik, admin, tata } \\
\text { usaha, biro keuangan. }\end{array}$ \\
\hline 5 & $\begin{array}{l}\text { Waktu } \\
\text { (When) }\end{array}$ & Spesifikasi waktu proses bisnis perkuliahan \\
\hline 6 & $\begin{array}{l}\text { Motivasi } \\
\text { (Why) }\end{array}$ & $\begin{array}{l}\text { Visi dan Misi Pusat Data dan Informasi Universitas Dian } \\
\text { Nuswantoro }\end{array}$ \\
\hline
\end{tabular}

\subsection{Perspektif Owner (Business Model)}

Perspektif ini menggambarkan sudut pandang pemilik atau orang yang bertanggung jawab pada sistem informasi akademik.

\section{a) Clasification What}

Pada gambar 3 terdiri dari use case dan skenario dengan tujuan untuk menggambarkan secara singkat dan requirement dari sistem yang akan dikembangkan.

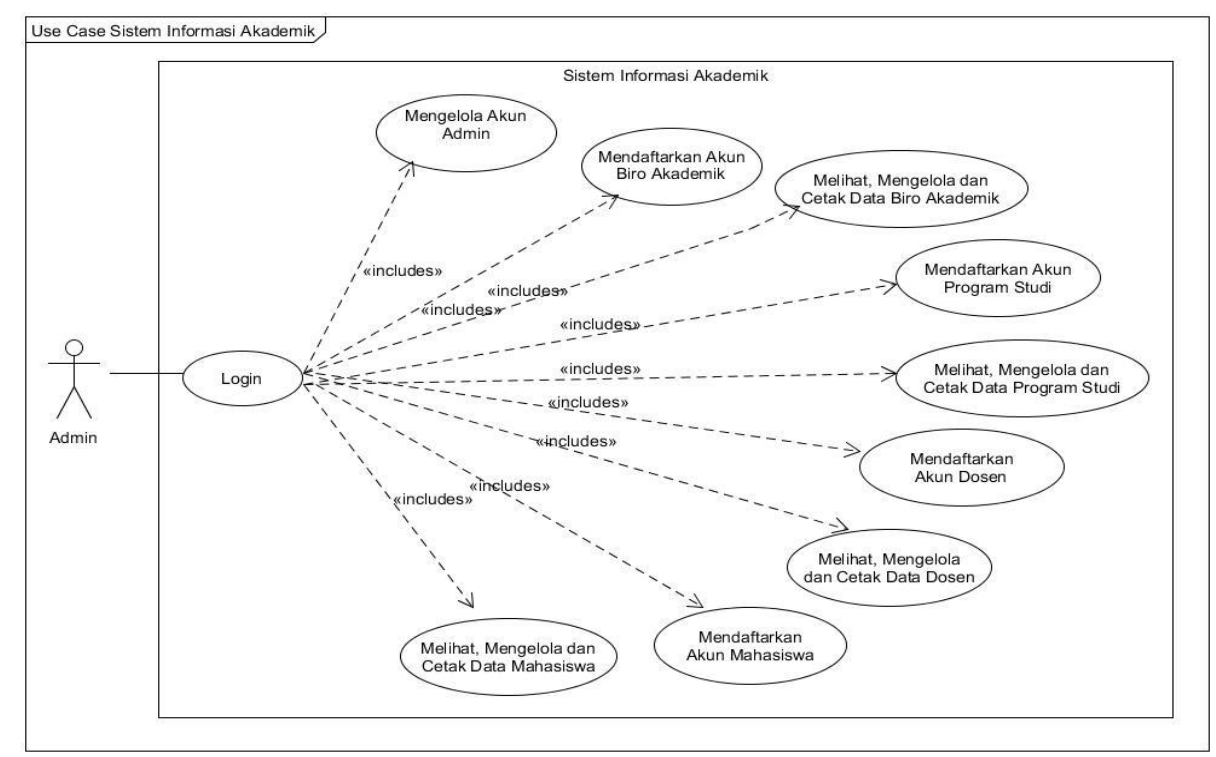

Gambar 3. Use case admin 
Pada gambar 3 admin dapat mengelola akun admin, mengelola data Biro Akademik, mendaftarkan akun Program Studi, mengelola data Program Studi, mengelola data dosen, mengelola data mahasiswa.

\section{b) Clasification How}

Sel ini menggambarkan dan mendeskripsikan secara rinci mengenai proses yang terjadi pada perspektif owner kolom what atau berdasarkan use case yang dibangun terdapat skenario pada masing-masing proses yang terjadi.

c) Clasification Where

Pada gambar 4 dibawah ini menggambarkan denah gedung Pusat Data dan Sistem Informasi Universitas Dian Nuswantoro Semarang berdasarkan sudut pandang owner.

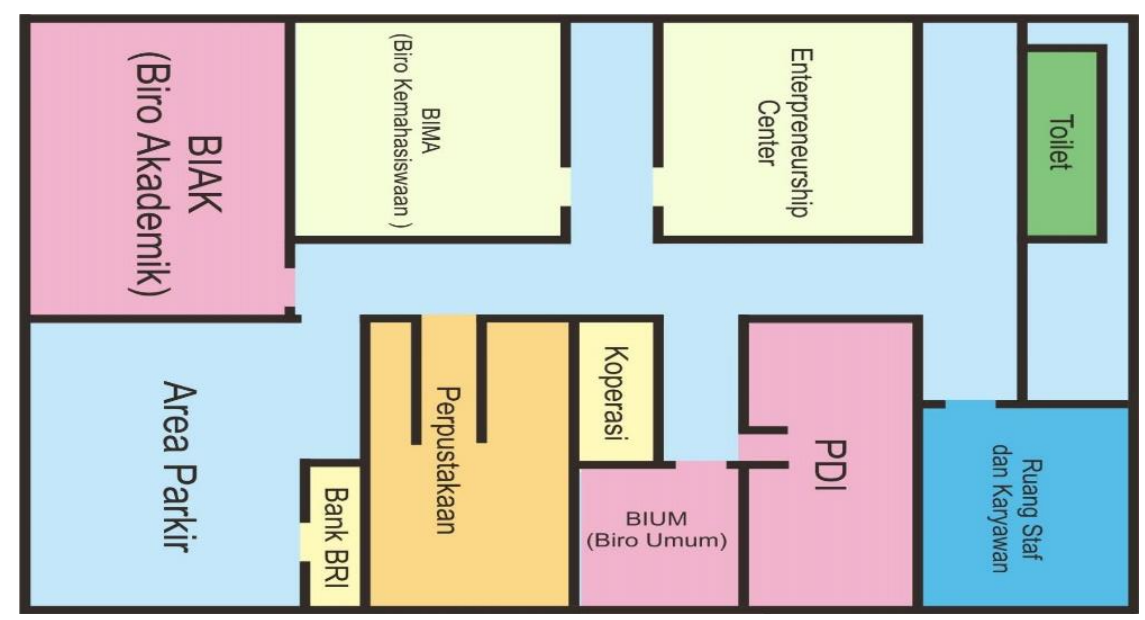

Gambar 4. Denah gedung pusat data dan informasi

\section{d) Clasification Who}

Sel ini menjelaskan mengenai sumber daya manusia atau orang-orang yang dipercayakan owner untuk menganalisis, membangun dan mengelola Sistem Informasi Akademik pada Pusat Data dan Informasi diantaranya yaitu administrator, analyst, programmer, penanggung jawab Sistem Informasi Akademik.

e) Clasification When

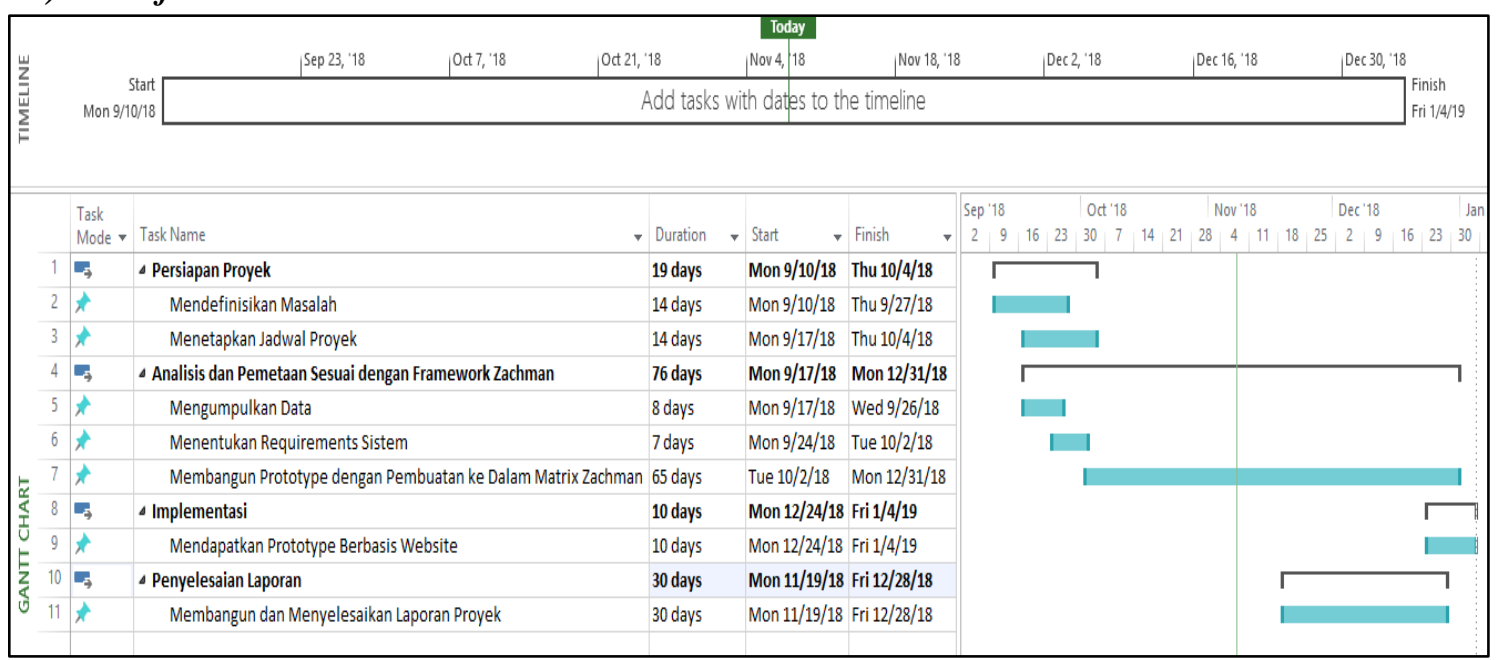

Gambar 5. Timeschedule berdasarkan sudut pandang owner

Pada gambar 5 mengambarkan tentang time schedule dalam mengembangkan Sistem Informasi Akademik Universitas Dian Nuswantoro Semarang berdasarkan sudut pandang owner dan digunakan sebagai panduan untuk melaksanakan penjadwalan berikutnya. 


\section{f) Clasification Why}

Sel ini menjelaskan tujuan dan alasan yang ingin dicapai oleh Unit Pelaksana Akademik Universitas Dian Nuswantoro Semarang terkait dengan adanya Sistem Informasi Akademik.

Tujuan dan alasan tesebut mencakup hal-hal seperti berikut:

1. Memberikan kemudahan pada Unit Pelaksana akademik dalam mendukung pencapaian proses bisnis Universitas Dian Nuswantoro.

2. Memberikan kemudahan kepada civitas akademik dalam menjalankan tugas dan tanggung jawab.

3. Mengembangkan sistem yang user friendly sehingga lebih mudah untuk diakses tanpa mengenal lokasi dan waktu. Meningkatkan keamanan penyimpanan data yang terotomatisasi.

4. Memberikan solusi kepada Universitas Dian Nuswantoro sehingga mampu untuk mendokumentasikan setiap proses yang dilakukan sistem.

5. Memberikan kemudahan pada Unit Pelaksana Akademik dan Pemimpin Universitas Dian Nuswantoro Semarang dalam memantau atau mengontrol ketercapaian seluruh proses bisnis yang diciptakan.

\subsection{Perspektif Designer (System Models)}

\section{a) Clasification What}

Sel what merupakan proses pendefinisian model dari sistem dengan merepresentasikan entitas-entitas dan atribut yang digunakan pada database Sistem Informasi Akademik dalam bentuk class diagram seperti yang ditunjukkan Gambar berikut:

\section{b) Clasification How}

Sel ini berfokus pada hasil use case yang terdapat pada sel what perspektif owner dalam Sistem Informasi Akademik Universitas Dian Nuswantoro. Berdasarkan sudut pandang designer sel ini berisi dengan sequence diagram dengan tujuan untuk menemukan behavioral pada setiap class yang sebelumnya telah didefinisikan.

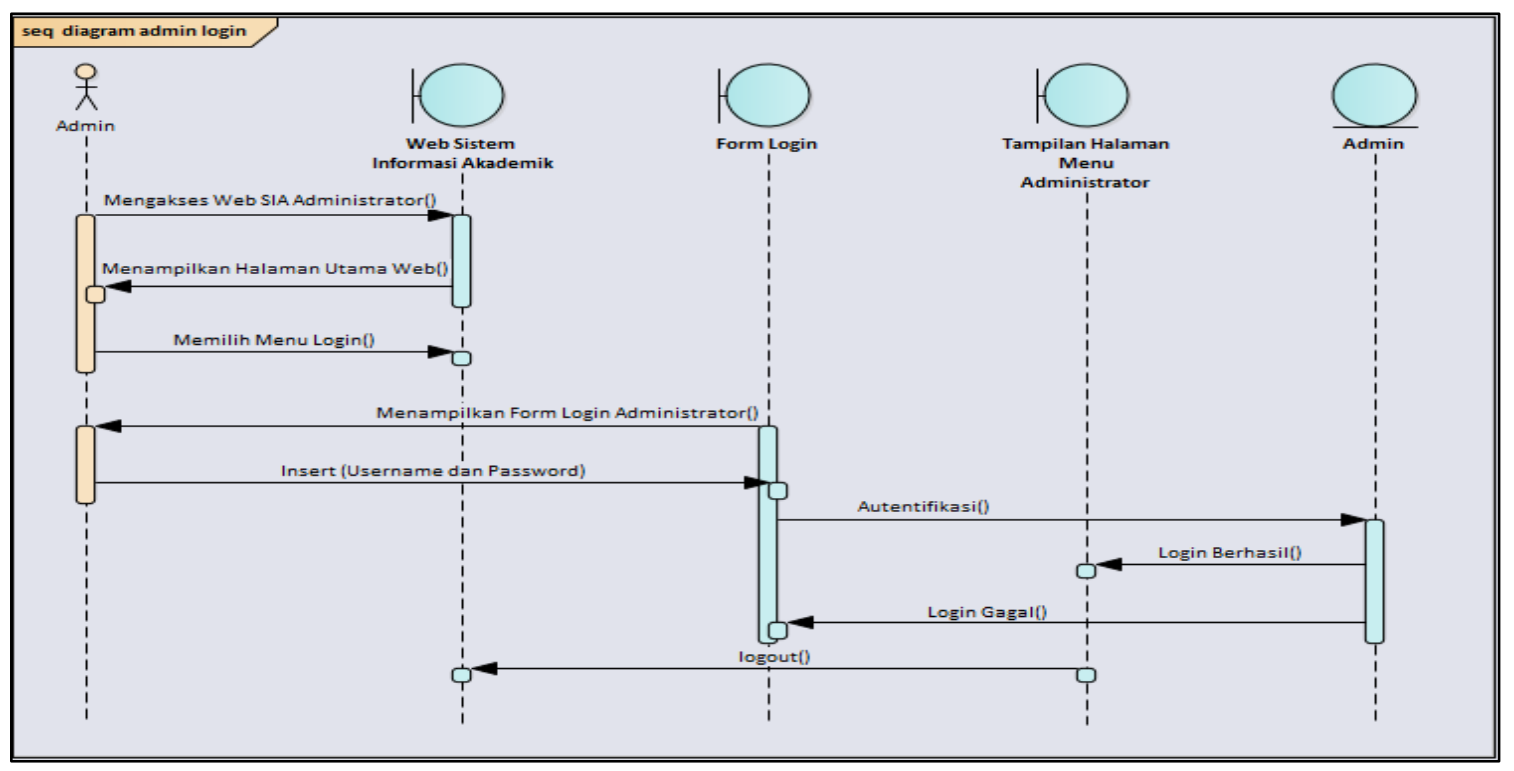

Gambar 6. Sequence diagram

Pada gambar 6 menggambarkan langkah-langkah yang dilakukan admin pada saat admin mengakses informasi yang berada pada website atau sistem informasi akademik.

\section{c) Clasification Where}

Sel ini merupakan gambaran terkait dengan desain jaringan yang sudah ada untuk dikembangkan Pusat Data dan Informasi. 
Sel ini berisikan desain input dan output manual sistem yang akan digunakan sebagai acuan dalam mengembangkan Sistem Informasi Akademik Universitas Dian Nuswantoro, Semarang.

e) Clasification When

Detail jadwal yang digunakan dalam melakukan perancangan model-model Sistem Informasi Akademik terdapat pada sel ini menurut sudut pandang dari designer.

\section{f) Clasification Why}

Sel ini berisikan aturan dan batasan-batasan yang digunakan dalam proses perancangan pengembangan Sistem Infomasi Akademik menurut sudut pandang dari designer.

\subsection{Perspektif Builder (Technology Physics)}

\section{a) Clasification What}

Pada gambar 7. berisikan pemetaan class diagram yang dapat menggambarkan relasi antar tabel dari database dengan mendeskripsikan tipe dari field yang digunakan dalam pengembangan sistem.

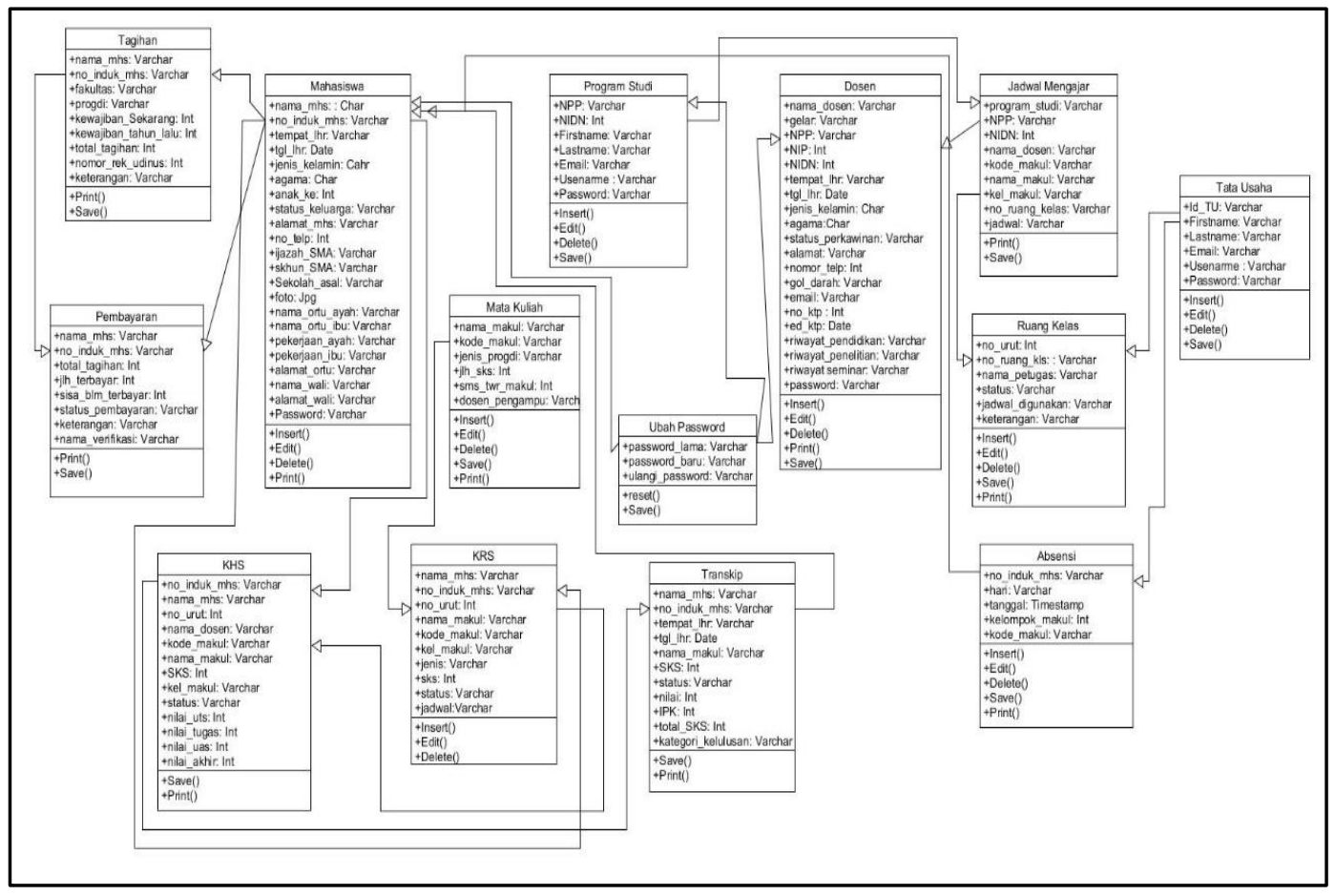

Gambar 7. Class diagram

\section{b) Clasification How}

Pada gambar 8 memberikan gambaran atau merepresentasiskan keseluruhan alur proses proses bisnis yang dikembangkan pada Sistem Informasi Akademik Universitas dian Nuswantoro, Semarang. Terdapat 7 entitas yang terlibat pada sistem informasi akademik yaitu mahasiswa, program studi, biro keuangan, dosen wali, biro akademik, tata usaha dan dosen.

\section{c) Clasification Who}

Sel ini merupakan sel yang berhubungan dengan perspektif designer abstraksi who, dimana bagain ini menggambarkan dan merupakan implementasi dari rancangan yang telah dibangun atau disebut dengan prototype, seperti berikut ini:

\section{d) Clasification When}

Sel ini digambarkan bahwa waktu atau jadwal yang digunakan untuk membangun Sistem Informasi Akademik sebagai model aplikasi fisik, dimana desain pada perspektif sebelumnya digunakan secara optimal yaitu batasan teknologi, orang, biaya, dan waktu berdasarkan sudut pandang builder. 


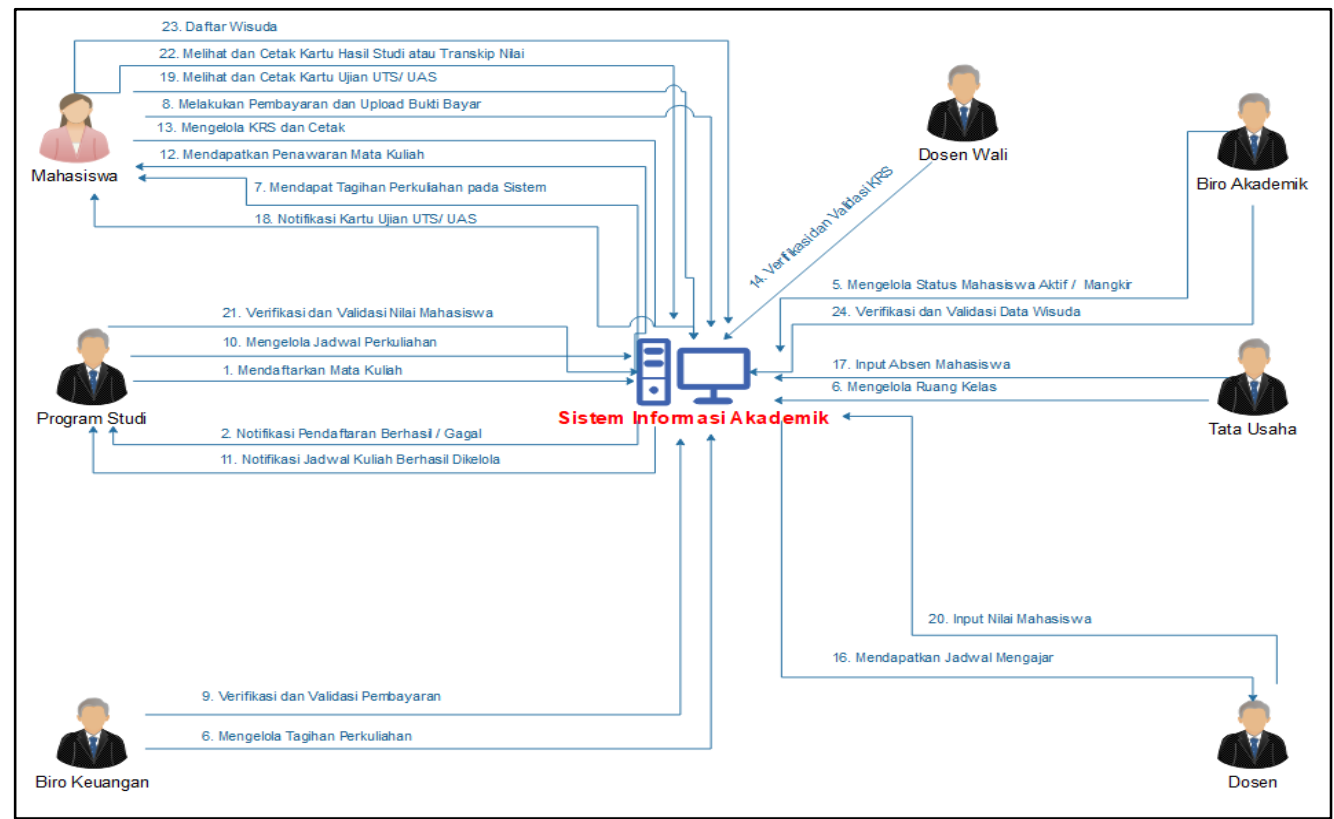

Gambar 8. Business core process

\section{e) Clasification Where}

Pemetaan dilakukan pada sel ini menurut sudut pandang dari builder dengan hasil gambaran terkait dengan teknologi arsitektur enterprise atau dalam hal ini gambar teknologi jaringan seperti pada gambar 9:

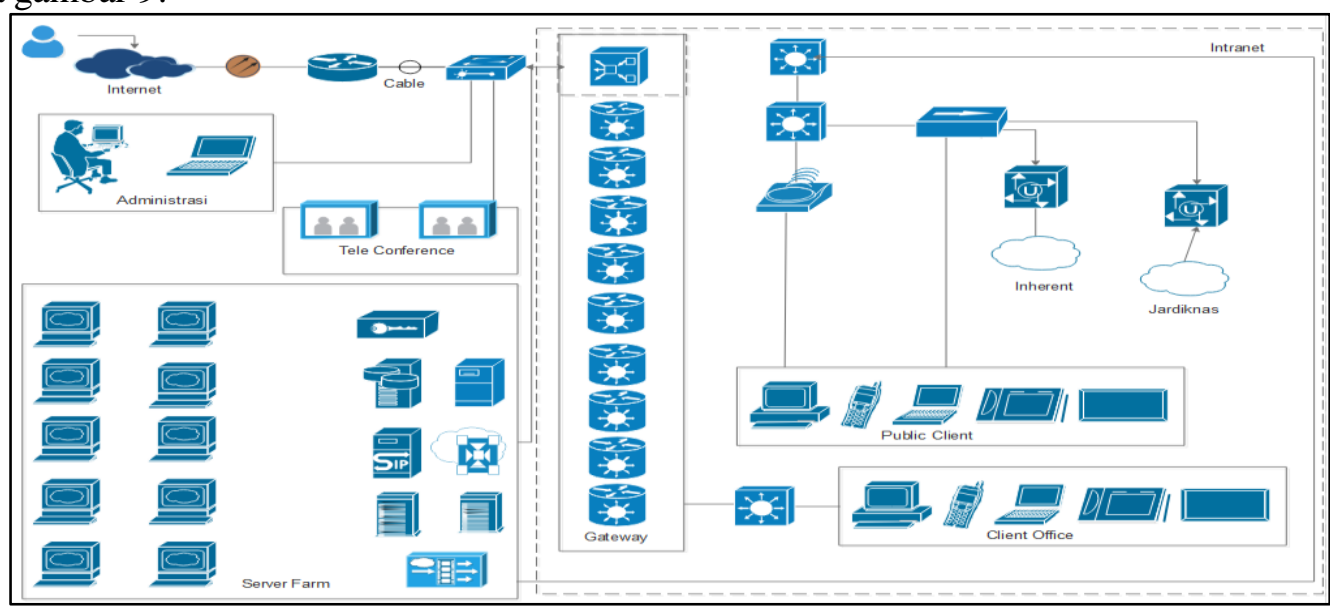

Gambar 9. Arsitektur enterprise jaringan yang menjalankan SIADIN

\section{f) Clasification Why}

Kolom ini berisi mengenai aturan dan batasan dalam membangun dan mengembangakan sistem berdasarkan desain yang telah dibuat.

\subsection{Perspektif Detail Representation (Component Assemblies)}

\section{a) Clasification What}

Tabel dari setiap entitas yang dibangun terdapat dalam sel ini, sehingga membentuk satu kesatuan Basis Data Sistem Informasi Akademik seperti gambar 10 yang merepresetasikan sejumlah tabel yang digunakan pada sistem. 


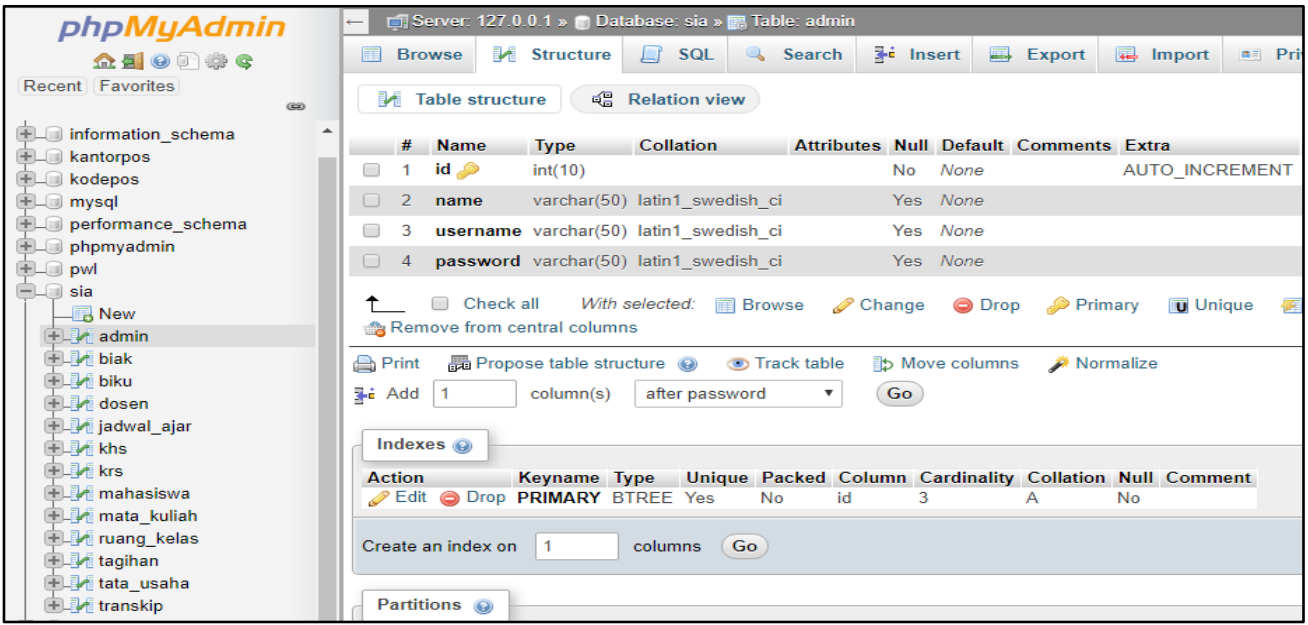

Gambar 10. Tabel database SIADIN

\section{b) Clasification How}

Sel ini menggambarkan dan menjelaskan secara rinci mengenai proses yang terjadi pada perspektif owner kolom what atau berdasarkan use case yang dibangun terdapat activity diagram pada masing-masing proses yang terjadi

\section{c) Clasification Where}

Sel ini memberikan penjelasan mengenai kebutuhan sistem dan kebutuhan perangkat keras yang akan digunakan Pusat Data dan Informasi dalam mengoperasikan Sistem Informasi Akademik yang dibangun.

\section{d) Clasification Who}

Pengguna atau users dalam Sistem Informasi Akademik yang dikembangkan terdiri dari enam yaitu admin, biro akademik, dosen, program studi, mahasiswa dan tata usaha.

\section{e) Clasification When}

Sel ini menjelaskan mengenai timeschedule atau jadwal yang dibutuhkan dalam menyusun algoritma kode program atau menyusun coding sehingga dihasilkan Sistem Informasi Akademik menurut sudut pandang sub-contractor.

\section{f) Clasification Why}

Dalam membangun dan mengembangkan kode pemograman atau coding terdapat beberapa batasan ataupun aturan yang penting untuk diperhatikan berdasarkan perspektif subcontractor.

\subsection{Perspektif Function Enterprise}

Berbagai macam panduan bagi user untuk menfungsikan system, melakukan manajemen operasi, dan mengevaluasi system jelaskan pada tabel 2.

Tabel 2. Pemetaan pada perspektif function enterprise terhadap 6 abstraksi

\begin{tabular}{ccl}
\hline No. & Abstraksi & \multicolumn{1}{c}{ Keterangan } \\
\hline 1 & Data & Pada sel ini akan ditampilkan data telah diisi pada database yang \\
& (What) & telah terkoneksi dengan prototype atau mengisi data pada tabel-tabel \\
& yang sudah disediakan sebagai representasi atau implementasi \\
& sebagian dari sel perspektif detail representation dengan klasifikasi \\
& what. Data yang diisi merupakan beberapa dari sekian banyak data \\
& yang dimiliki Universitas Dian Nuswantoro, dimana data tersebut \\
& dapat berubah atau bertambah sesuai dengan kebutuhan instansi atau \\
& pada saat dilakukan implementasi Sistem Informasi Akademik \\
& Prototype yang telah dibangun akan dilakukan pengujian sebagai \\
& tahap sebelum dilakukan implementasi yang dapat diupdate sesuai \\
& dengan kebutuhan atau permintaan dari stakeholders maupun owner \\
& Pusat Data dan Informasi. Dimana pada sel ini akan diberikan contoh \\
& dari hasil cetak dari Sistem Informasi Akademik yang diuji. \\
\hline
\end{tabular}




\begin{tabular}{ccl}
\hline 3 & $\begin{array}{c}\text { Jaringan } \\
\text { (Where) }\end{array}$ & Nama dan type dari infranstrutur jaringan. \\
4 & $\begin{array}{c}\text { Orang } \\
\text { (Who) }\end{array}$ & Beberapa contoh user atau pengguna Sistem Informasi Akademik. \\
5 & $\begin{array}{c}\text { Waktu } \\
\text { (When) }\end{array}$ & Beberapa contoh user atau pengguna Sistem Informasi Akademik \\
6 & $\begin{array}{c}\text { Motivasi } \\
\text { (Why) }\end{array}$ & $\begin{array}{l}\text { Timeschedule pengembangan Sistem Informasi Akadeik secara } \\
\text { keseluruhan. } \\
\text { Prosedur untuk mengakses Sistem Informasi Akademik. }\end{array}$ \\
\hline
\end{tabular}

\subsection{Blueprint IT}

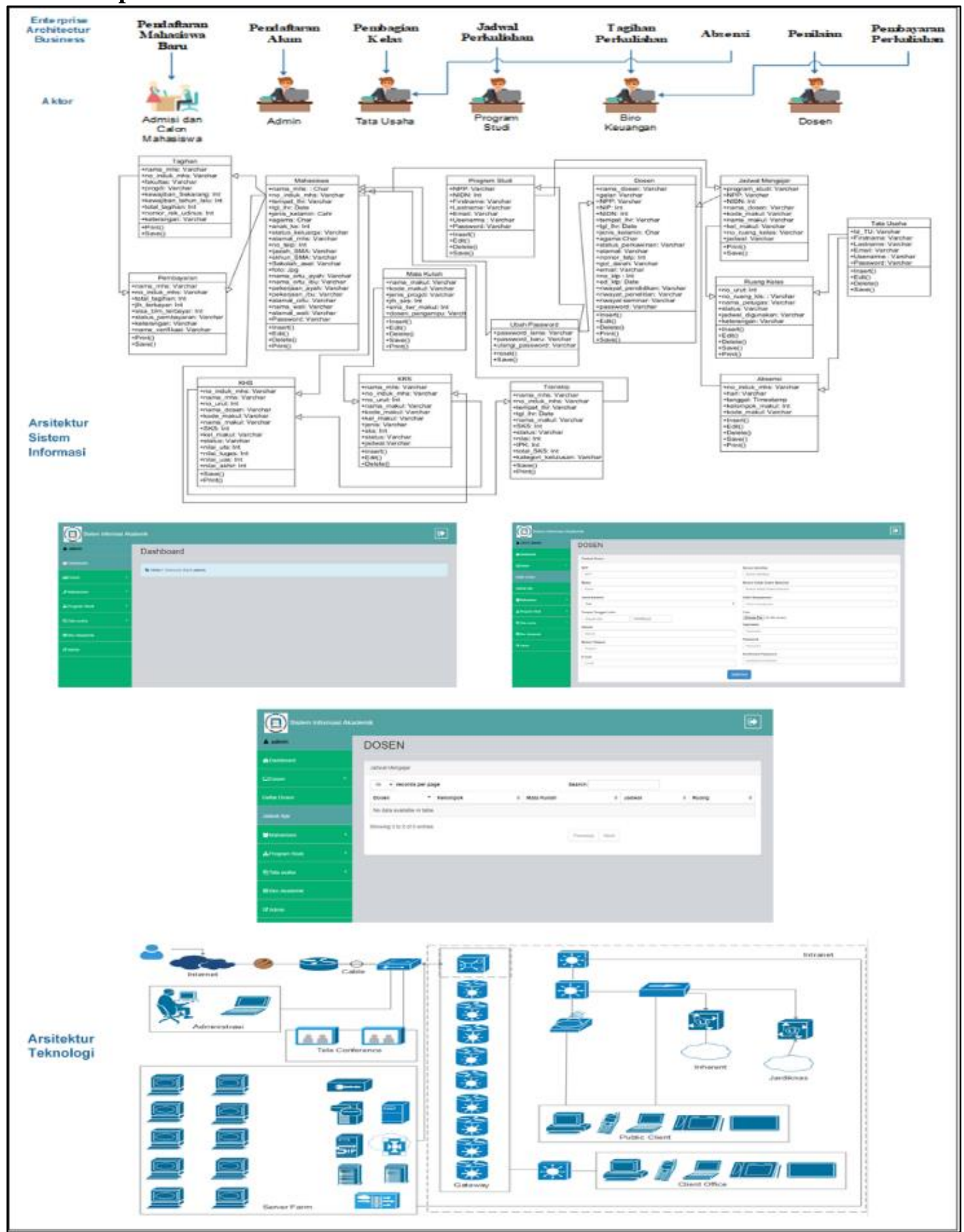

Gambar 11. Blueprint IT Sistem Informasi Akademik Universitas Dian Nuswantoro 
Pada gambar 11 diperolehlah suatu gambaran tentang blueprint IT pada sistem akademik Universitas Dian Nuswantoro dan prototype berbasis Objected Oriented Programming yang dapat digunakan sebagai acuan untuk membangun, mengembangkan dan mendokumentasikan sistem.

\section{KESIMPULAN}

Berdasarkan hasil analisis pengembangan enterprise architecture yang dilakukan dengan memetakan kedalam 36 sel pada Zachman Framework diperoleh enterprise architecture Sistem Informasi Akademik yang dijelaskan secara eksplisit sehingga lebih mudah untuk memahaminya demikian dibuat kesimpulan sebagai berikut:

1. Zachman Framework dapat digunakan untuk membangun Sistem Informasi Akademik Universitas Dian Nuswantoro dengan hasil berupa cetak biru (blueprint). Cetak biru atau blueprint tersebut dapat digunakan oleh Pusat Data dan Informasi baik analyst, desainer, dan programmer sebagai referensi untuk menggembangkan sistem.

2. Prototype yang dihasilkan merupakan Sistem Informasi Akademik Admin yang dibangun berdasarkan cetak biru (blueprint) disesuaikan dengan perspektif planner (scope), Owner (business model), designer (system model), builder (technology physics), detail representation (component assemblies), function enterprise (operation classes).

3. Zachman Framework membantu memberikan solusi atas permasalahan yang ada pada Pusat Data dan Informasi, hal ini ditunjukkan dengan pemetaan terhadap setiap perspektif merupakan proses untuk mendokumentasikan setiap aktivitas untuk membangun dan mengembangkan sistem informasi akademik universitas dian nuswantoro

\section{SARAN}

Dari hasil penelitian yang disimpulkan pada sub sebelumnya, diharapkan dengan adanya penelitian ini dapat dimanfaatkan untuk penelitian selanjutnya sebagai bahan referensi penelitian. Berdasarkan penelitian yang telah dilakukan, beberapa saran yang diberikan untuk memperbaiki Sistem Informasi Akademik supaya lebih baik.

1. Sistem Informasi Akademik yang dikembangkan dapat mengintegrasikan antar fungsi dalam sistem informasi akademik.

2. Akan menjadi efektif apabila pada sistem informasi akademik yang dioperasikan oleh mahasiswa menjadi satu kesatuan dengan sistem untuk input Kartu Rencana Studi.

3. Dapat dilakukan penelitian lebih lanjut terkait dengan sistem informasi yang lain guna mendukung proses pencapaian tujuan, visi dan misi yang dimiliki oleh Pusat Data dan Informasi Universitas Dian Nuswantoro.

4. Penelitian berikutnya untuk melengkapi keluaran atau output dari penelitian ini, seperti mengintegrasikan core process, management process dan support process.

5. Melakukan pengembangan enterprie arsitektur Sistem Informasi Akademik menggunakan framework yang lain seperti TOGAF, FEAF dan lain-lain.

\section{DAFTAR PUSTAKA}

[1] I. Susanti and Y. Kusumawati, "Rancang Bangun E-Marketplace dengan Model Prototyping pada Dinas Koperasi dan Umkm Provinsi Jawa Tengah,” Semarang, 2017.

[2] I. P. Solihin and M. B. Wibisono, "Desain Kebijakan Sistem Informasi dan Teknologi Informasi Dengan Framework Zachman Pada Perguruan Tinggi Negeri Baru di Jakarta," J. RESTI (Rekayasa Sist. dan Teknol. Informasi), vol. 1, no. 3, pp. 266-276, 2017.

[3] H. A. Mumtahana, W. W. Winarno, and A. Sunyoto, "Perancangan Arsitektur Sistem Informasi Akademik STT Dharma Iswara Madiun dengan Zachman Framework," vol. 2, no. 2 . 
[4] P. Blueprint, I. T. Dengan, Z. Framework, and D. I. Stp, "Jurnal Sistem Informasi ( Journal of Information Systems ). 1 / 13 ( 2017$)$, 49-66 DOI: http://dx.doi.org/10.21609/jsi.v13i1.528," vol. 13, pp. 49-66, 2017.

[5] J. Informa, P. Indonusa, and S. Issn, "Dengan Permodelan Enterprise Architecture Zachman Framework," vol. 1, 2016. 